\title{
Two new dinoflagellate cysts from the Middle Jurassic of the Barents Sea Region
}

\author{
MORTEN SMELROR \\ Continental Shelf and Petroleum Technology Research Institute, N-7034 TRONDHEIM, Norway
}

\begin{abstract}
Two new Peridinioid dinoflagellate cyst species are described from Middle Jurassic strata of the Barents Sea Region. Phallocysta thomasi sp.nov. occurs in Aalenian-Bajocian sediments cored from the Nordkapp Basin and Valvaeodinium thereseae sp. nov. occurs in Upper Bathonian-Callovian deposits cropping out on Kong Karls Land and Franz Josef Land.
\end{abstract}

\section{INTRODUCTION}

Dinoflagellates provide good biostratigraphic resolution within the Middle and Upper Jurassic successions of the Barents Sea, and are recognized as a prime tool for dating and correlation. Consequently, in recent years extensive studies of the Jurassic dinoflagellate assemblages of the Barents Sea Shelf have been carried out by biostratigraphers at different research institutes and at oil companies involved in the exploration of this frontier region. Valuable information has been made available through the IKU Arctic Geoprogram on Svalbard and the IKU Shallow Drilling Program on the Barents Shelf. Much of the biostratigraphic information gained from the exploration activities are still unreleased, but published accounts of Jurassic dinoflagellates from these areas included the papers of Below (1987a, 1987b), Bjœrke (1978, 1980a, 1980b), Bjœrke et al. (1976), Bjœrke and Dypvik (1977), Dypvik et al. (1985), Smelror (1987, 1988, 1989), Smelror and Below (1990), Smelror and Århus (1989), Thusu (1978) and Wierzbourski and Århus (1990). In this present paper, two new Middle Jurassic peridinioid dinoflagellate cysts are formally described: Phallocysta thomasii sp.nov. and Valvaeodinium therese $i$ sp.nov. These new taxa may potentially serve as useful biostratigraphic markers for the Aalenian-Bajocian and Late Bathonian-Middle Callovian Stages, respectively.

\section{SYSTEMATIC DESCRIPTIONS}

Order Peridiniales Haeckel 1984

Genus Phallocysta Dörhöfer \& Davies 1980, emend. Below 1987 Type Species. Phallocysta eumekes Dörhöfer \& Davies 1980 , emend. Below 1987

\section{Phallocysta thomasi sp.nov.}

(Pl. 1, figs 11-20)

Derivation of name: Named after my son Thomas.
Holotype: Pl. 1, fig. 16

Paratype: P1. 1, fig.14

Type locality and horizon: IKU shallow core 7230/05-U-02, depth: $67.29 \mathrm{~m}$, Nordkapp Basin, Barents Sea Region.

Description: Proximate dinoflagellate cyst, peridinioidal, more or less elongated in overall outline. The epicyst is coniform tapering into an (often prominent) apical horn. Hypocyst generally rounded with two moderately well developed half-ovaloid protrusions. Cyst wall with numerous small uniformly distributed spines (mostly accuminate/ evexate, but occasionally also capitate). No clear evidence of paratabulation has been observed, except for the archeopyle, which is anterior intercalary type $3 \mathrm{I}$ (i.e. comprising the $1 \mathrm{a}+2 \mathrm{a}+3 \mathrm{a}$ plates). Dimensions: Length $45-56 \mathrm{~mm}$, (hypocyst) width $22-40 \mathrm{~mm}$. Stratigraphic distribution: IKU Core 7230/05-U-02:67.29-81.30m, Aalenian-Bajocian, Dodekovia bullula - Nannoceratopsis senex Zone and lower Nannoceratopsis gracilis Zone of Smelror and Below (1990).

Remarks: Phallocysta eumekes Dörhöfer \& Davies (1980), P erregulensis (Filotoff) Stover \& Helby 1987 and $P$. minuta Prauss 1989 differ from Phallocysta thomasi sp.nov, in being epicavate and not possessing any prominent ornamentation. Phallocysta frommernensis Below 1987 is proximate but has a well developed scabrate ornamentation.

Genus Valvaeodinium Morgenroth 1970, emend. Below 1987 Type species. Valvaeodinium armatum Morgenroth 1970

Valvaeodinium thereseae sp.nov.

(Pl. 1, figs 1-10)

Derivation of name: Named after my daughter Therese

Holotype: Pl.1, fig. 5

Paratype: Pl. 1, fig. 3 


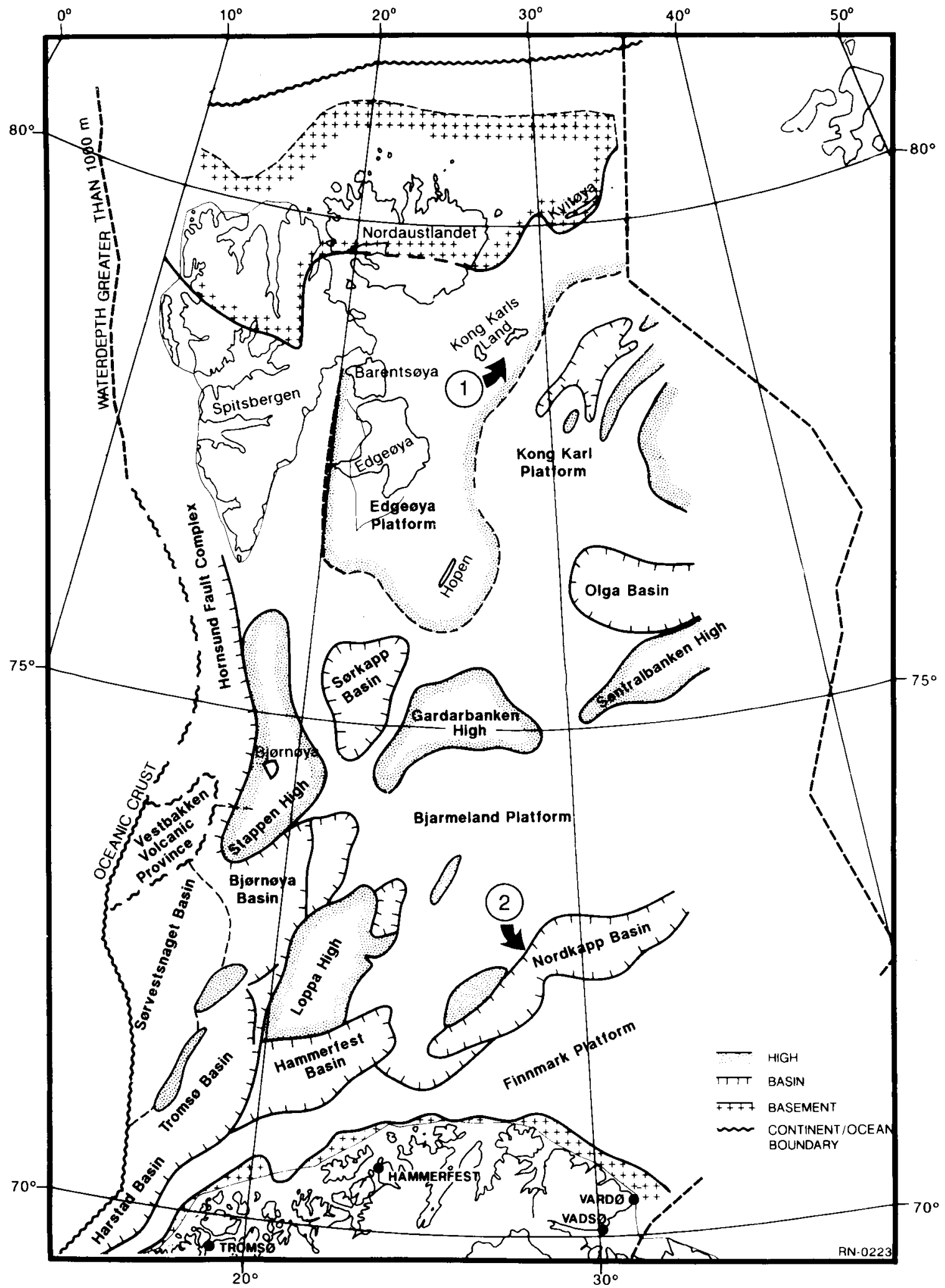

Fig. 1. Map of the Barents Sea Region, showing the main structural elements and the positions of the type localities of the dinoflagellate species described herein: 1) Kong Karls Land Hårfagrehaugen section. 2) Nordkapp Basin, corehole 7230/05-U-02. (Based on Gabrielsen et al. 1990). 
Middle Jurassic dinoflagellate cysts
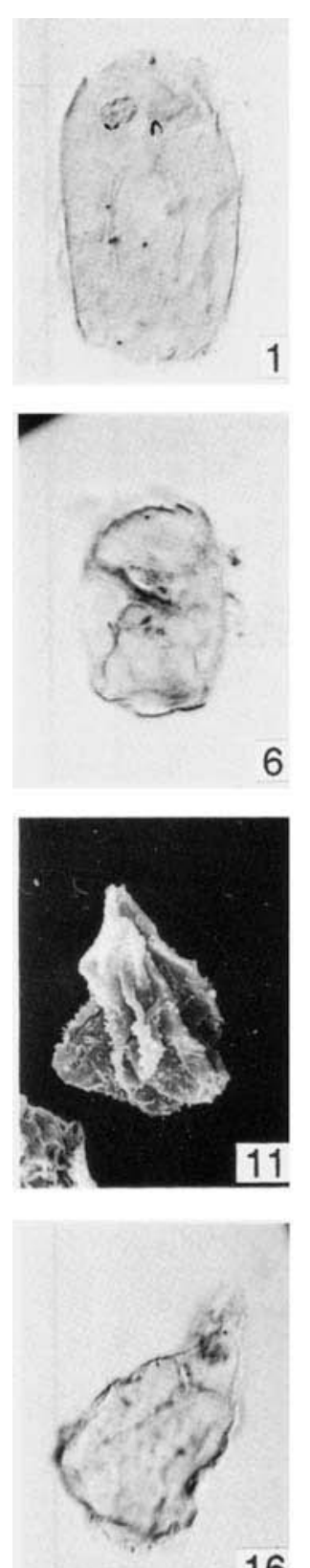

16
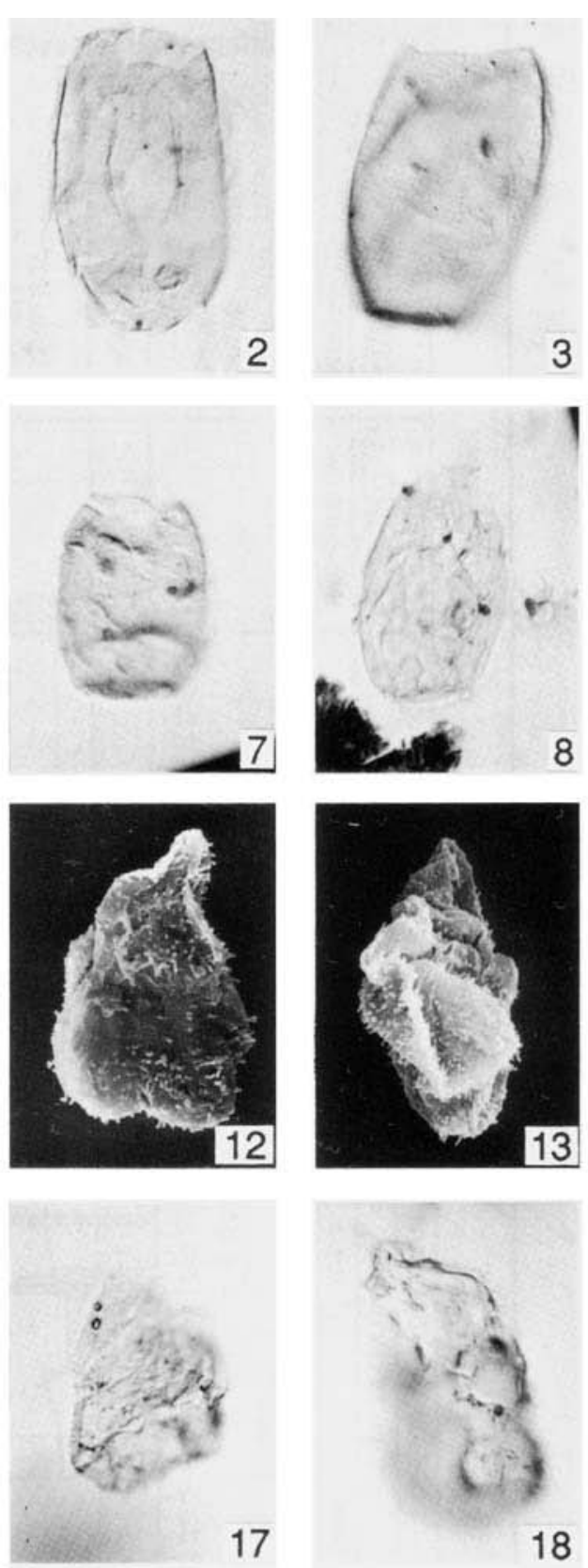
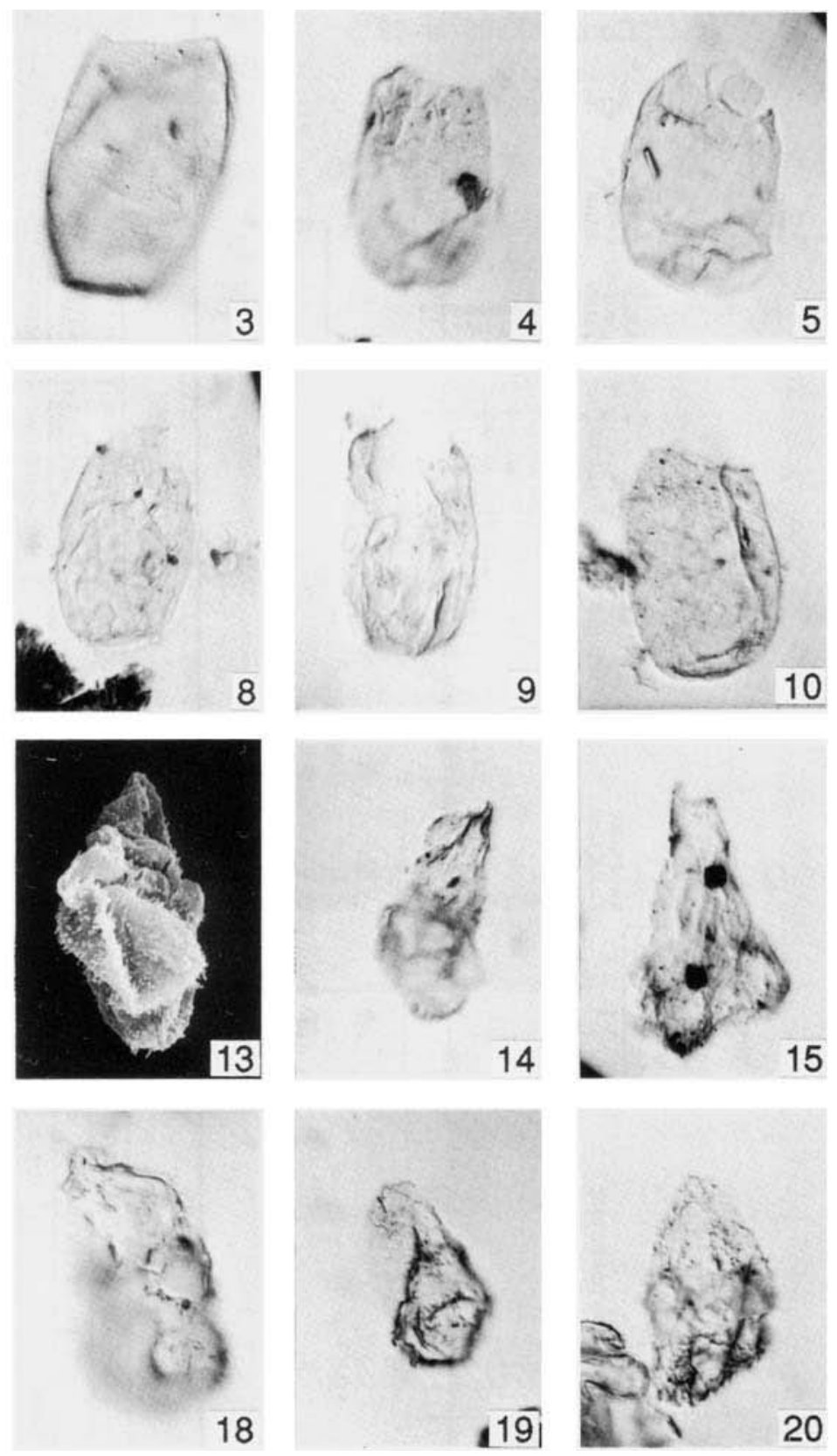

\section{Explanation of Plate 1}

All magnification x 500, except Figures 11-13 x 525 All illustrated specimens are housed in the type collection of the Paleontological Museum, Oslo (Norway). (Collection numbers: PA 4386, PA 4387, PA 4404 and PMO 121469).

Figs 1-10, Valvaeodinium thereseae sp.nov. Figs 1-2, PA 4404, S-14/42-1, Q39/2 Fig.3, PA 4386, CFU-OX, M 32/3. Paratype Fig.4, PA 4387,WG-2OSB, H 23/1 Fig. 5, PA 4404, S14/42-1, J 53/1.Holotype Fig. 6, PA 4387, WG-2 OXB, Q 29/0 Fig.7, PA 4387,

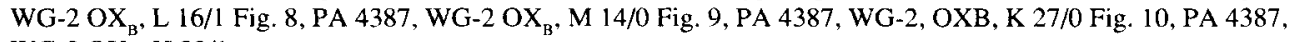
WG-2 OX, H 23/1

Figs 11-20, Phallocysta thomasi sp.nov. Fig. 11, PMO 121469, 7230/05-U-02, 67.29m, SEM-I Fig. 12, PMO 121469, 7230/05-U-02, 67.29m, SEM-I Fig. 13, PMO 121469, 7230/05-U-02, 67.29m, SEM-I Fig. 14, PMO 121469/05-U-02, 67.29m, M 41/2. Paratype Fig. 15 . PMO 121469, 7230/05-U-02, 67.29m, T 523 Fig. 16, PMO 121469, 7230/05-U-02, 67.29m A 44/4. Holotype Fig. 17, PMO 121469, 7230/05-U-02, 67.29m, Q 46/0 Fig. 18, PMO 121469, 7230/05-U-02, 67.29m J 51/4 Fig. 19, PMO 121469, 7230/05-U-02, 67.29m, D 43/0 Fig. 20, PMO 121469, 7230/05-U-02, 67.29m, G 53/3 


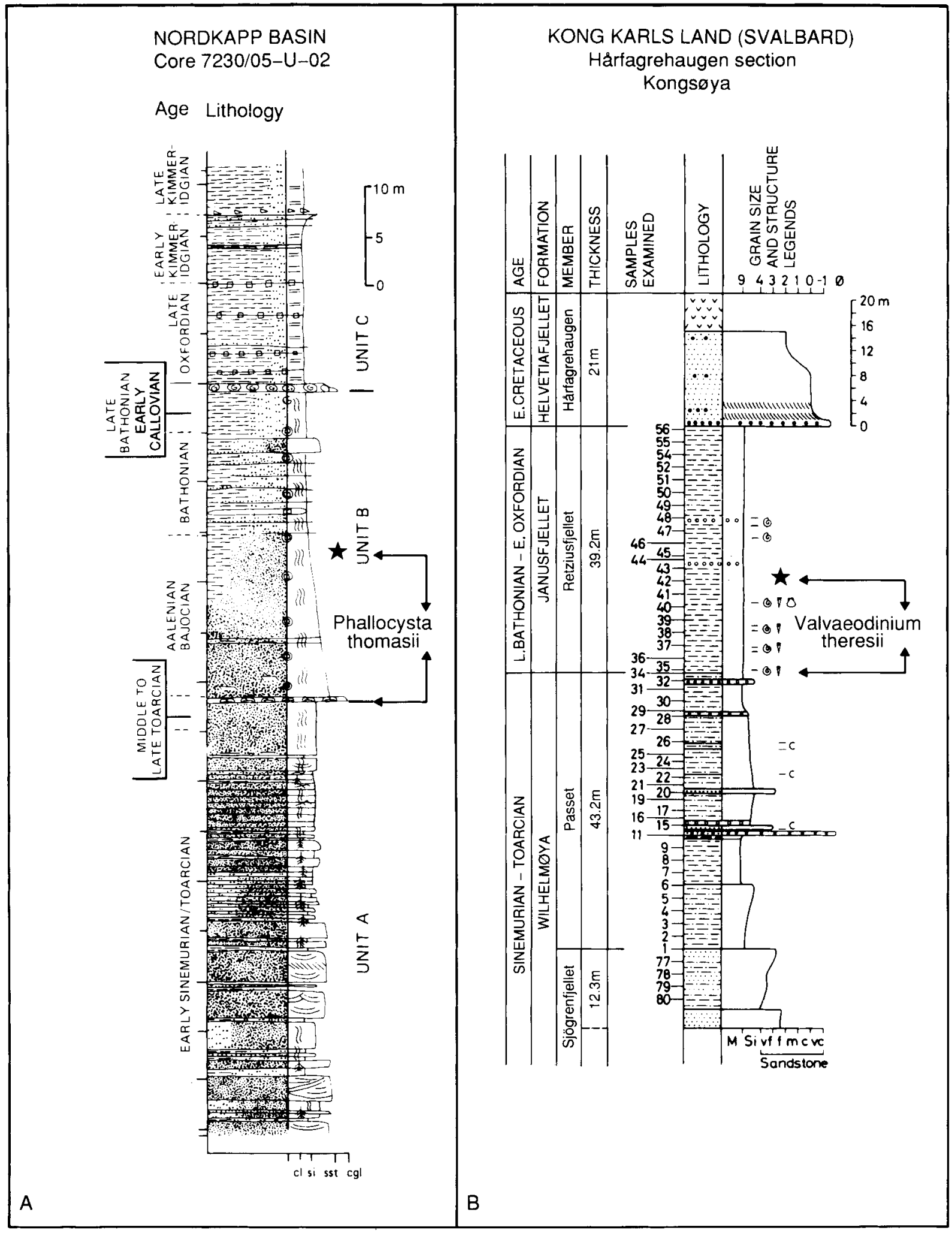

Fig. 2. Lithostratigraphical logs of A) core 7230/05-U-02 in the Nordkapp Basin and B) the Hårfagrehaugen section on Kongsøya, Kong Karls Land (Svalbard). The type horizons of Phallocysta thomasi sp.nov. and Valvaeodinium thereseae sp.nov. are indicated by *. Recorded stratigraphic distribution of these two species in the type sections are shown to the right of the lithological columns. Fig. $2 \mathrm{~A}$ is from unpublished core log prepared by G. Elvebakk. Fig.2B is from Løfaldli and Nagy (1980). See Fig 3 for key. 
Type locality and horizon: Svalbard, Kong Karls Land, Hårfagrehaugen section, Sample S-14/42-1.

Description: Proximate dinoflagellate cyst, circumcavate, ellipsoidal to cylindrical in outline, antapex rounded. Cingulum and sulcus not marked. Ectophragm is scabrate, thin and hyaline, endophragm is generally finely granular. Ectophragm is frequently torn and disrupted. The archeopyle is apical/anterior intercalary, type $2 \mathrm{~A}$ (i.e. comprising the $3^{\prime}+1$ a platres in the kofoidian notation). Paratabulation, except for the archeopyle and assessory archeopyle sutures is obscure.

Dimensions: Endocyst: width 25-35mm, length 45-55mm.Pericyst: width $28-43 \mathrm{~mm}$, length $46-59 \mathrm{~mm}$ (15 specimens measured).

Stratigraphic distribution: Kong Karls Land (Svalbard) Hårfagrehaugen section: Retziusfjellet Member 0-12.4m above base, Late Bathonian-Middle Callovian. Northbrook Island (Franz Josef Land, Arctic Soviet), Windy Gully section, sample WG-2 (151m above sea level), Late Bathonian.
More information about the palynomorph assemblages found in the Hårfagrehaugen and Windy Gully sections are found in Smelror (1989 and 1988, respectively). V. thereseae sp.nov. is found in the Sirmiodinium grossi Zone and Meiourogonoyanlax planoseptataChlamydophorella ectotabulata Zone of Smelror and Below (1990). Remarks: The morphology of the genus Valvaeodinium has been thoroughly documented by Below (1987), and to my knowldege Valvaeodinium thereseae is the only circumcavate species attributed to this genus. This species was originally described and illustrated as ?Leberidocysta sp. SA by Smelror 1988 (p. 294, 296, pl. III figs 8, 11). In this previous description based on a limited number of specimens, it was not possible to determine the archeopyle outline and it was only suggested to be apical.

Manuscript received December 1990

Manuscript accepted June 1991

\begin{tabular}{|c|c|c|c|}
\hline \multicolumn{4}{|c|}{ LEGENDS } \\
\hline & Fig. $2 A$ & & Fig.2B \\
\hline$=0$ & Clay, shale & $E=$ & Clay, shale \\
\hline$\because \cdots \cdots \cdots$ & Siltstone & $-\div=$ & Siltstone \\
\hline m & Sandstone & 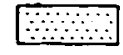 & Sandstone \\
\hline एक्व & Conglomerate & 000000 & I Nodules \\
\hline & $\begin{array}{l}\text { Mudstone clast } \\
\text { Pyrite }\end{array}$ & $\cdots \cdots$ & Conglomerate \\
\hline$|\rightarrow| \lambda\rangle$ & Increasing bioturbation & $\because 200$ & Basalt \\
\hline $\begin{array}{l}\text { 喿 } \\
\text { (D) }\end{array}$ & $\begin{array}{l}\text { Roots } \\
\text { Nodules }\end{array}$ & $\begin{array}{l}c \\
0 \\
\nabla \\
0\end{array}$ & $\begin{array}{l}\text { Coal seam } \\
\text { Ammonites } \\
\text { Belemnites } \\
\text { Bivalves }\end{array}$ \\
\hline
\end{tabular}

Fig.3. Legends to the lithostratigraphical logs in Fig. 2. (A: core 7230/05-U-02) B: Hårfagrehaugen section).

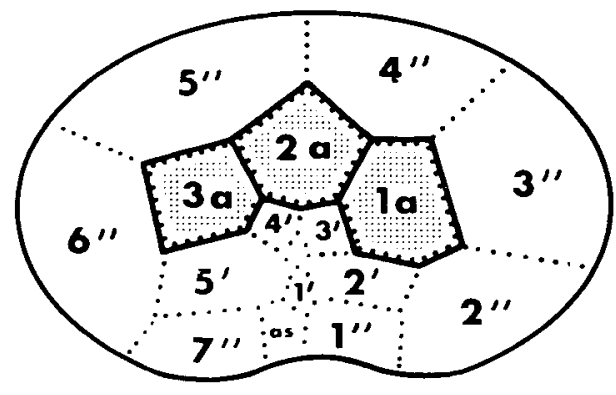

A.

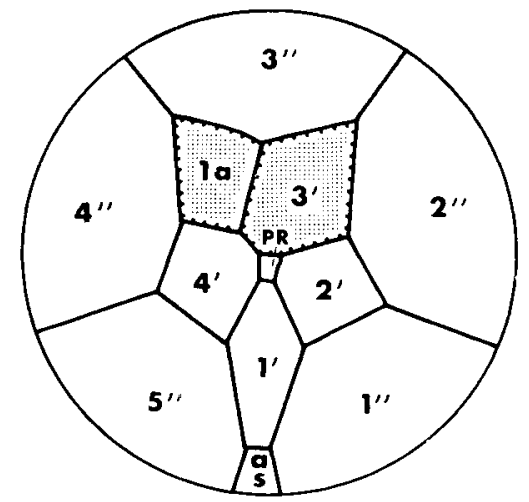

B.

Fig. 4. Hypocyst-paratabulation of A:Phallocysta frommernensis Below 1987 and B: Valvaeodinium armatum Morgenroth 1970. (From Below 1987a and 1987b, respectively). 


\section{REFERENCES}

Below, R. 1987a. Evolution und Systematic von Dinoflagellaten-Zysten aus der Ordnung Peridiniales. I. Allgemeine Grundlagen und Subfamilie Rhaetogonyaulacoideae (Familie Peridiniaceae). Palaeontographica Abt. $B, 205,1-164$

Below, R. 1987b. Evolution und Systematik von Dinoflagellaten-Zysten aus der Ordnung Peridiniales. II. Cladopyxiaceae und Valvaeodiniaceae. Palaeontographical Abt. B, 206, 1-115.

Bjœrke, T. 1977. Mesozoic Palynology of Svalbard. II. Palynomorphs from the Mesozoic sequence of Kong Karls Land. Norsk Polarinstitutt Årbok 1976. 83-120.

Bjœrke, T. 1980a. Mesozoic palynology of Svalbard. IV. Toarcian dinoflagellates from Spitsbergen. Palynology, 4, 57-77.

Bjœrke, T. 1980b. Mesozoic palynology of Svalbard. V. Dinoflagellates from the Agardhfjellet Member (Middle and Upper Jurassic) in Spitsbergen. Norsk Polarinstitutt Skrifter 172, 145-167.

Bjorke, T., Edwards, 'M.B. \& Thusu, B. 1976. Microplankton from the Janusfjellet Subgroup (Jurassic-Lower Cretaceous) at Agardhfjellet, Spitsbergen. A preliminary report. Norsk Polarinstitutt Årbok 1974, 63-68.

Bjorke, T. \& Dypvik, H. 1977. Sedimentological and palynological studies of Upper Triassic-Lower Jurassic sediments in Sassenfjorden, Spidsbergen. Norsk Polarinstitutt Årbok 1976, 131-150.

Dypvik, H., Hvoslef, S., Bjœrke, T. \& Finnerud, E. 1985. The Wilhelmøya Formation (Upper Triassic-Lower Jurassic) at Bohemanflya, Spitsbergen. Polar Research, 3, 155-165.

Gabrielsen, R.H., Fœrseth, R.B., Jensen, L.N., Kalheim, J.E. \& Riis, R. 1990. Structural elements of the Norwegian continental shelf, Part I: The Barents Sea Region. NPD Bulletin, No. 6, 33pp.

Løfaldli, M. \& Nagy, N. 1980. Foraminiferal stratigraphy of the Jurassic deposits on Kongsøya, Svalbard. Norsk Polarinstitutt, Skrifter 172, 63-95.

Smelror, M. 1987. Bathonian and Callovian (Middle Jurassic) dinoflagellate cysts and acritarchs from Franz Josef Land, Arctic Soviet. Polar Research, 5, 221-238

Smelror, M. 1988. Bathonian to Early Oxfordian dinoflagellate cysts and acritarchs from Kong Karls Land, Svalbard. Rev. Palaeobot. Palynol., 56, 275-304.

Smelror, M. 1989. Chlamydophorella ectotabulata sp.nov., a gonyaulacoid dinoflagellate cyst from the late Bathonian to the Oxfordian of the arctic. Rev. Palaeobot. Palynol., 61, 139-145.

Smelror, M. \& Århus, N. 1989. Emendation of the dinoflagellate cyst genus Crussolia Wolfard \& van Erve 1981, and description of $C$. dalei n.sp. from the Callovian of Svalbard. N.Jb. Geol. Paläont, Mh. 1988, 37-46.

Smelror, M. \& Below, R. 1990. Dinoflagellate biostratigraphy of the Toarcian to Lower Oxfordian (Jurassic) of the Barents Sea Region. Abstract, Norwegian Petroleum Society International Conference on Arctic Geology and Petroleum Potential, Troms $\phi, 1990$, p.50.

Thusu, B. 1978. Aptian to Toarcian dinoflagellate cysts from Arctic Norway. In: B. Thusu (ed.): Distribution of biostratigraphically diagnostic dinoflagellate cysts and miospores from the Northwest European continental shelf and adjacent areas. Continental Shelf Inst. Publ., 100, 61-95.

Wierbowski, A. \& Århus, N., 1990. Ammonite and dinoflagellate cyst succession of an Upper Oxfordian-Kimmeridgian black shale core from the Nordkapp Basin, southern Barents Sea. Newsl. Stratigr., 22, 7-19 